\title{
Combined Role of Fe Nanoparticles (Fe NPs) and Staphylococcus aureus L. in the Alleviation of Chromium Stress in Rice Plants
}

\author{
Hesham F. Alharby ${ }^{1}$ and Shafaqat Ali ${ }^{2,3, *}$ \\ 1 Department of Biological Sciences, Faculty of Science, King Abdulaziz University, Jeddah 21589, Saudi Arabia; \\ halharby@kau.edu.sa \\ 2 Department of Environmental Science and Engineering, Government College University, \\ Faisalabad 38000, Pakistan \\ 3 Department of Biological Sciences and Technology, China Medical University, Taichung 40402, Taiwan \\ * Correspondence: shafaqataligill@gcuf.edu.pk
}

check for updates

Citation: Alharby, H.F.; Ali, S. Combined Role of Fe Nanoparticles (Fe NPs) and Staphylococcus aureus L. in the Alleviation of Chromium Stress in Rice Plants. Life 2022, 12, 338 https://doi.org/10.3390/ life12030338

Academic Editor: Balazs Barna

Received: 21 January 2022

Accepted: 18 February 2022

Published: 24 February 2022

Publisher's Note: MDPI stays neutral with regard to jurisdictional claims in published maps and institutional affiliations.

Copyright: (C) 2022 by the authors. Licensee MDPI, Basel, Switzerland. This article is an open access article distributed under the terms and conditions of the Creative Commons Attribution (CC BY) license (https:// creativecommons.org/licenses/by/ $4.0 /)$.

\begin{abstract}
Chromium ( $\mathrm{Cr}$ ) is a toxic heavy metal whose high concentration in soil badly affects plant growth, photosynthesis, and overall yield. Metal-derived nano-particles and metal-resistant bacteria can strengthen the plant defense system against different abiotic stresses; however, little is known about the use of nanoparticles in conjunction with bacteria. This study examined the combined effect of Fe nanoparticles (Fe NPs) and a chromium-resistant bacterium Staphylococcus aureus, on rice plants grown on chromium saturated medium. Chromium stress reduced rice growth, biomass, and chlorophyll contents by causing oxidative damage leading to overproduction of electrolyte leakage, hydrogen peroxide, and malondialdehyde. Fe NPs significantly improved plant growth, biomass, yield, and photosynthetic activity by enhancing the chlorophyll contents and alleviating oxidative damage. Application of Fe NPs also reduced the uptake and accumulation of $\mathrm{Cr}$ in the plants by increasing the bioavailability of micronutrients to the plant. The Fe NPs decreased oxidative damage and enhanced the enzymatic and non-enzymatic activity in the plant to withstand Cr stress compared to the plants without Fe NPs treatments. The inoculation of rice plants with the chromium-resistant bacteria $S$. aureus further enhanced the positive impact of Fe NPs by transforming the toxic form of chromium $\left(\mathrm{Cr}^{6+}\right)$ into a less toxic form of chromium $\left(\mathrm{Cr}^{3+}\right)$. The bacterial inoculation reduced $\mathrm{Cr}$ uptake by plants through adsorption of $\mathrm{Cr}$ ions, resulting in decreased chromium ion bioavailability. At chromium level $100 \mathrm{mg} / \mathrm{kg}$, the foliar application of Fe NPs from 0 to $20 \mathrm{mg} / \mathrm{L}$ increased the total chlorophyll contents from 2.8 to 3.9. The application of $S$. aureus further enhanced the chlorophyll contents from 4.4 to 5.4, respectively. The current study suggested that combining Fe NPs and $S$. aureus could be a viable strategy for reducing $\mathrm{Cr}$ toxicity and accumulation in rice plants and most likely other plants.
\end{abstract}

Keywords: chromium; physiological parameters; oxidants; antioxidants; rice; heavy metals

\section{Introduction}

Soil pollution, caused by the discharge of toxic metals, has become a major environmental issue worldwide. Chromium $(\mathrm{Cr})$ is a toxic metal element whose chemical compounds are widely distributed in the atmosphere due to industrial waste, primarily tannery effluents, metallurgy, and rapid urbanization [1,2]. When aggravated, $\mathrm{Cr}$ compounds reach our food chains; their high persistence and soil availability can be absorbed or stored in plants (directly or indirectly), thus causing harmful effects on human health when the latter are consumed [3]. Phytotoxic effects are known to be extreme in plant species grown in $\mathrm{Cr}$-contaminated areas. The toxic effect and cancerous properties of chromium (VI) have been renowned for a long time. Water-insoluble chromium (III) compounds and chromium metal, on the other hand, are not considered harmful [2]. Chromium can easily travel to various plant parts and can be 
accumulated there before being consumed by animals and humans [4]. Chromium harms plants by reducing plant height and root growth, interrupting germination, unbalancing nutrient levels, and causing photosynthesis damage [5]. Further chromium exposure slows soil microbial activity, inhibits enzyme activity, and triggers the formation of reactive oxygen species (ROS), leading to plant oxidative stress [6]. Chromium can lead to many problems in human biological systems, including death in those exposed to it.

Rice (Oryza sativa L.) is the most commonly consumed cereal grain, with over half of the world population eating it as a staple meal. After sugarcane and maize, it is the agricultural commodity with the third-highest global output (741.5 million metric tons). It is grown in more than 100 countries worldwide, accounting for $21 \%$ of the world's total caloric intake and up to $76 \%$ of the population of Southeast Asia [7]. Rice is high in carbohydrates, which serve as fuel for the body. It also contains fiber, which aids digestion and lowers cholesterol and saturated fats, making it a heart-healthy meal [8]. The pollution of paddy rice by carcinogenic and harmful contaminants such as heavy metals has risen due to increased industrial growth, with the potential to imperil the entire food chain and, as a result, human health $[9,10]$. Rice is grown in flood-prone areas, which encourages the plant's mobilization and eventual accumulation of heavy metals [11,12]. The indiscriminate use of chemical products and waste originating from industry and agriculture are all main contributors to the rise and mobilization of toxic metals in rice plant tissues [12]. The four main processes for heavy metal accumulation in rice are root absorption, root-to-shoot translocation, redirection at nodes, and remobilization from leaves [13]. Cadmium (Cd), chromium $(\mathrm{Cr})$, lead $(\mathrm{Pb})$, mercury $(\mathrm{Hg})$, and arsenic (As) are among the heavy metals that are toxic to both plants and humans [14]. Hexavalent $\mathrm{Cr}\left(\mathrm{Cr}^{6+}\right)$ is more toxic than trivalent chromium $\left(\mathrm{Cr}^{3+}\right)$ due to an elevated oxidation state. Toxicity of $\mathrm{Cr}^{6+}$ interferes with various physiological functions in plants, including rice, resulting in a reduction in seed germination, development, and photosynthesis and increased changes in leaf protein profiles and root microRNA expression $[15,16]$. Previous studies found that induction of oxidative stress was the key biological mechanism underlying Cr toxicity in plants, based on the effect of $\mathrm{Cr}$ exposure on the roots of growing rice seedlings [17]. The activation of CDPK (calcium-dependent protein kinase) and NADPH (nicotinamide adenine dinucleotide phosphate) oxidase in response to $\mathrm{Cr}$ (VI) inhibits rice root growth by accumulating calcium and producing reactive oxygen species, respectively [18].

Nanotechnology is one of the promising scientific fields that have the potential to revolutionize agricultural production $[19,20]$. Biofortification of micronutrients is the process of enriching the nutrient content of crops to provide a long-term solution to nutrient deficiencies in agricultural products, mainly Fe and Zn deficiency [21]. The size, shape, reactivity, chemical compositions, and surface functionalization of various engineered NPs decide their performance $[19,22]$. The properties of these transition metal NPs and their growing applications in agriculture, biology, and biomedicine have prompted increased interest in their synthesis [23,24]. Micronutrients, especially Fe, play an essential role in various physiological, metabolic, and cellular processes in plants due to their ability to promote oxidation and reduction reactions [25]. Nanoparticles have been shown to affect microscopic soil properties such as humic acid content, bacterial communities, and plant growth and development [26]. Depending upon the properties of nanoparticles, the plants and NPs interaction may positively and negatively impact the plant's physiological, morphological, and molecular features [27]. The nanoscale metals and metal oxide may damage or improve the germination, plant growth, development, photosynthesis, and yield parameters [26]. Many studies reported that the application of iron oxide nanoparticles increased the germination, improved photosynthesis, reduced drought and metal stress and increased nutrients absorption, phytohormones production, and crops yield in maize, cotton, wheat, rice, tomato, and cereal crops [27-29].

Microorganisms play a crucial role in mineralizing pollutants, including heavy metals and the biogeochemical transformation of nutrients in the soil [30]. Microbes can reduce metal accumulation in plants by altering the redox state of metal species in the soil, result- 
ing in increased plant growth and biomass production. Chromium-reducing bacteria can reduce $\mathrm{Cr}^{6+}$ to $\mathrm{Cr}^{3+}$ in the rhizosphere through bioaccumulation and biosorption mechanisms, reducing $\mathrm{Cr}$ toxicity [31]. Staphylococcus aureus is a gram-positive, round-shaped, and chromium-reducing bacterium first-time isolated from tannery effluent [32].

The metals' nanoparticles and bacteria can promote plant growth and reduce the stress of metals' toxicity in plants. The combined role of nanoparticles and bacteria in alleviating metal-induced toxicity in plants has not been studied thoroughly. This study aimed to analyze the combined and individual roles of the chromium-reducing bacterium Staphylococcus aureus and Fe NPs to alleviate the chromium-induced $\left(\mathrm{Cr}^{6+}\right)$ toxicity in rice plants.

\section{Materials and Methods}

\subsection{Soil Sampling and Analysis}

The soil for this experiment was obtained from the field of the University of Agriculture, Faisalabad-Pakistan. The soil was sieved through a $2 \mathrm{~mm}$ sieve, and large debris was removed thoroughly. Initial soil characterization was accomplished by a standard procedure such as particle size by hydrometer [33]. The electrical conductivity (EC) of saturated soil paste was measured by a calibrated EC meter. Similarly, the pH of the soil paste with a 1:25 soil to water ratio was noted by calibrated $\mathrm{pH}$ meter. The soil was treated with ammonium bicarbonate diethylene triamine penta acetic acid (AB-DTPA) at $\mathrm{pH} 6.7$ to analyze the available trace elements in the selected soil [34]. The standard procedure was used to determine pseudo total metals in the soil [35], which is described in Table 1.

Table 1. Physico-chemical analysis of soil samples from the field of the University of Agriculture, Faisalabad, Pakistan.

\begin{tabular}{cc}
\hline Soil & Units \\
\hline Textural Class & Sandy Clay Loam \\
Sand & $63.7 \%$ \\
Silt & $14.4 \%$ \\
Clay & $21.9 \%$ \\
$\mathrm{pH}$ & 7.71 \\
$\mathrm{EC}$ & $1.93 \mathrm{dS} \mathrm{m}^{-1}$ \\
$\mathrm{HCO}_{3}^{-1}$ & $3.1 \mathrm{mmol} \mathrm{L}^{-1}$ \\
Total nitrogen & $0.06 \%$ \\
Available P & $2.7 \mathrm{mg} \mathrm{kg}^{-1}$ \\
$\mathrm{~K}^{+}$ & $0.08 \mathrm{mmol} \mathrm{L}^{-1}$ \\
$\mathrm{Cl}^{-1}$ & $5 \mathrm{mmol} \mathrm{L}^{-1}$ \\
$\mathrm{Ca}^{+2}+\mathrm{Mg}^{+2}$ & $14.34 \mathrm{mmol} \mathrm{L}^{-1}$ \\
Available Cd $^{-1}$ & $0.06 \mathrm{mg} \mathrm{kg}^{-1}$ \\
\hline
\end{tabular}

\subsection{Seed Inoculation}

Seeds of the rice were inoculated with chromium-resistant bacteria. For this purpose, peat moss as a source of bacterial inoculation was obtained from the Ayub Agriculture Research Institute, Faisalabad, Punjab, Pakistan. The soil was dried adequately at $70{ }^{\circ} \mathrm{C}$ for $72 \mathrm{~h}$, then grounded and sieved through a $2 \mathrm{~mm}$ sieve and autoclaved at $121{ }^{\circ} \mathrm{C}$ for $20 \mathrm{~min}$ to eliminate bacterial contamination. The bacterial inoculum was synthesized by nutrient broth and Cr-resistant bacteria (Staphylococcus aureus), added to the inoculum, and shaken at $2000 \mathrm{rpm}$ for $48 \mathrm{~h}$ at $30^{\circ} \mathrm{C}$ for $48 \mathrm{~h}$. The density of bacterial isolates was measured by hemocytometer. After $48 \mathrm{~h}$ of shaking, the inoculum was added into the conical tubes from the flasks and centrifuged at $6000 \mathrm{rpm}$ for $10 \mathrm{~min}$. The supernatant was removed and diluted with distilled water to re-suspend the pellets [36]. The population size of centrifuged bacterial cells was adjusted at $2.8 \times 10^{8}$ wet weight. The seeds of rice were disinfected by inoculum with a $10 \%$ sugar solution. Then, the seeds were adequately coated with clay, and peat moss took in equal amounts (1:1) and was placed overnight. 


\subsection{Pot Experiment}

A pot experiment was set up at the botanic yard of Government College University, Faisalabad-Pakistan, at a temperature of $18-25{ }^{\circ} \mathrm{C}$ with a humidity of $70 \%$. Sieved soil was mixed with various chromium concentrations $(0,50$, and $100 \mathrm{mg} / \mathrm{kg}) \mathrm{using} \mathrm{K}_{2} \mathrm{Cr}_{3} \mathrm{O}_{7}$ as $\mathrm{Cr}^{6+}$ source. Each plastic container was filled with $5 \mathrm{~kg}$ of soil, and five rice seeds were sown in each pot. Thinning was performed after germination, and only two healthy seedlings were preserved. For healthy growth, nitrogen, phosphorus, and potassium were applied at 120:50:2 Kg/ha. Plants were sprayed with varying concentrations of Fe nanoparticles (0, 10, and $20 \mathrm{mg} / \mathrm{L}$ ) after two weeks of germination, while controls were treated with filtered water. Fe NPs was purchased from Alfa Aesar. The characterization revealed the purity of Fe NPs $\left(\mathrm{Fe}_{3} \mathrm{O}_{4}\right.$. Iron (II, III) oxide) was 97\%, size 50-100 nm and density 5.2 and also used in our previous study [37].

\subsection{Growth and Physiological Parameters}

After four months of treatment, plants were harvested by chopping the shoots around $1 \mathrm{~cm}$ high from the soil. The harvested plants were cut into various sections, washed, and dried in the oven for $72 \mathrm{~h}$ at $70^{\circ} \mathrm{C}$, and their dry weight was measured. Roots were washed with $1 \% \mathrm{HCl}$ and rinsed properly with filtered water to ensure the complete removal of acid, and dry weight of roots were noted.

Growth parameters such as plant height $(\mathrm{cm})$, root and shoot length $(\mathrm{cm})$, and spike length (cm) were measured by meter scale. The number of leaves per plant was counted, and the fresh and dry biomass of root and shoot was measured by weighing balance. Chlorophyll $\mathrm{a}, \mathrm{b}$, total chlorophyll, and carotenoids contents were determined by a method followed by Lichtenthaler [38]. To quantify the chlorophyll contents, the samples were extracted in $85 \%$ acetone and $15 \%$ distilled $\mathrm{H}_{2} \mathrm{O}_{2}(v / v$ ratio) and were centrifuged, and readings were taken using a spectrophotometer at specified $(645,480$, and $663 \mathrm{~nm})$ wavelengths.

\section{5. $\mathrm{MDA}, \mathrm{EL}, \mathrm{H}_{2} \mathrm{O}_{2}$, and Antioxidants Enzymes}

Malondialdehyde (MDA) content was determined by the procedure described by Zhang and Kirham [39]. Electrolyte leakage (EL) was measured by the Dionisio-Sese and Tobita [40] method. First, samples were extracted in trichloroacetic acid (TCA) solution at $32{ }^{\circ} \mathrm{C}$ for $2 \mathrm{~h}$, after which the first EC of the solution was recorded. Then, the procedure was repeated at $121^{\circ} \mathrm{C}$ for $20 \mathrm{~min}$, after which the final EC of the solution was documented. Following Jana and Choudhuri's [41] procedure, the contents of $\mathrm{H}_{2} \mathrm{O}_{2}$ were estimated. These samples were homogenized before centrifugation by adding $50 \mathrm{Mm}$ phosphate buffer at $\mathrm{pH} 6.5$, then centrifuged for $20 \mathrm{~min}$. After that, $\mathrm{H}_{2} \mathrm{SO}_{4}(20 \% v / v)$ was added to the ultra-spin separated mixture and centrifuged for another $15 \mathrm{~min}$. At a wavelength of $410 \mathrm{~nm}$, the intake was detected. For an estimate of POD and SOD contents, specimens were macerated in liquid nitrogen and then systemized in phosphate buffer with $0.5 \mathrm{M}$ at $7.8 \mathrm{pH}$ [42]. APEX activities were assessed using the Nakano and Asada [43] technique, while CAT activity was calculated using the Aebi [44] method.

\subsection{Metal Contents}

In order to determine the amount of iron $(\mathrm{Fe})$ and chromium $(\mathrm{Cr})$ in roots, shoots, and grain samples, $1 \mathrm{~g}$ of each sample was processed in a heated plate with a 4:1 ratio of $\mathrm{HNO}_{3}$ : $\mathrm{HClO}_{4}(v / v)$. The amount of metal was measured in processed samples using an atomic absorption spectrophotometer (AAS) [45].

\subsection{Statistical Analysis}

ANOVA was used to assess statistics using SPSS (Statistics Programming, Version 21) at a probability level of 5 percent. For various method differentiations, Tukey's HSD post hoc test was performed. 


\section{Results}

\subsection{Growth Parameters}

The application of $\mathrm{Cr}$ drastically affected the growth of the rice plants (Figure 1). The growth was gradually decreased when the $\mathrm{Cr}$ concentration in the growth medium increased from 25 to $100 \mathrm{mg} \mathrm{kg}^{-1}$. The high concentration of $\mathrm{Cr} 100 \mathrm{mg} \mathrm{kg}^{-1}$ caused a significant reduction in the length of the shoot, roots, shoot and root dry weight, number of tillers, and leaf area. Fe NPs had a significant impact on plant growth and improved plant growth even at a high chromium concentration compared to plants without Fe NPs. The increasing concentration of Fe NPs from 0 to $20 \mathrm{mg} \mathrm{L}^{-1}$ significantly improved plant growth. The inoculation of S. aureus L. in combination with Fe NPs further enhanced the plant growth and reduced the effect of chromium toxicity on plants compared to plant without Fe NPs and bacterial inoculation. The data regarding plant growth attributes indicated that the combined application of $S$. aures and Fe NPs significantly improved the rice growth and dry biomass under $\mathrm{Cr}$ stress conditions.
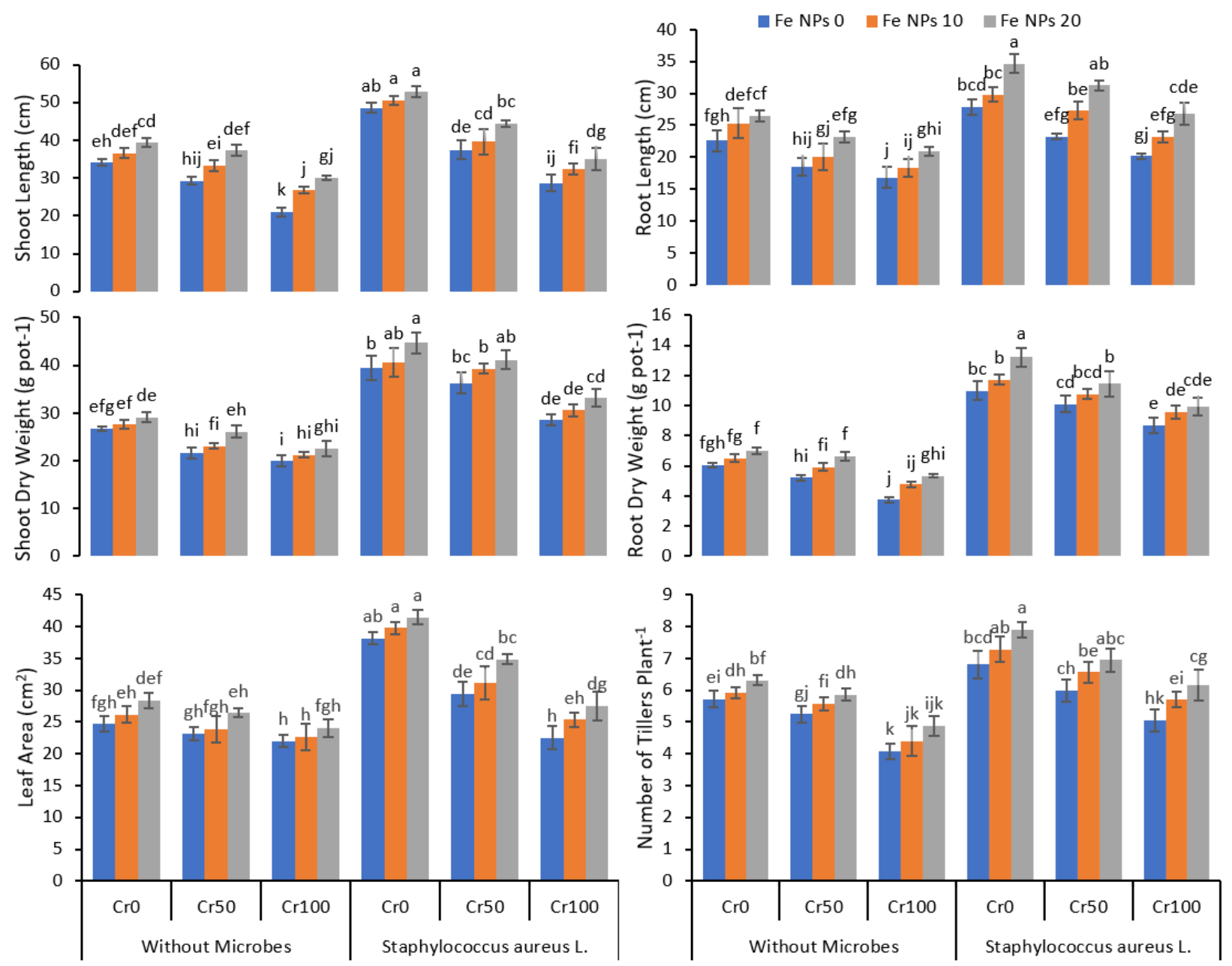

Figure 1. Combined effects of Fe nanoparticles (NPs) $\left(0,10\right.$, and $\left.20 \mathrm{mg} \mathrm{L}^{-1}\right)$ and S. aureus L. on growth parameters of rice grown under $\mathrm{Cr}$ stress $\left(0,50\right.$, and $\left.100 \mathrm{mg} \mathrm{kg}^{-1}\right)$. The mean values of three replicates together with their standard deviation are shown in the plots. Various small letters denote significant differences between different treatments at $p \leq 0.05$.

\subsection{Chlorophyll Contents}

The increasing concentration of $\mathrm{Cr}$ gradually decreased chlorophyll a, chlorophyll b, total chlorophyll, and carotenoids concentration (Figure 2). The increasing concentration of $\mathrm{Cr}$ from 0 to $100 \mathrm{mg} \mathrm{kg}^{-1}$ reduced the chlorophyll contents from $2 \mathrm{mg} \mathrm{g}^{-1} \mathrm{FW}$ to 
$1.8 \mathrm{mg} \mathrm{g}^{-1} \mathrm{FW}$ in treatments without microbes and Fe NPs application. The application of Fe NPs ( 0 to $20 \mathrm{mg} \mathrm{kg}^{-1}$ ) improved the chlorophyll contents from 1.8 to $2.4 \mathrm{mg} \mathrm{g}^{-1} \mathrm{FW}$ despite increasing $\mathrm{Cr}$ from 0 to $100 \mathrm{mg} \mathrm{kg}^{-1}$. The inoculation coupled with Fe NPs further enhanced the chlorophyll a, chlorophyll $\mathrm{b}$, and total chlorophyll and carotenoids contents in the rice plants under chromium stress.
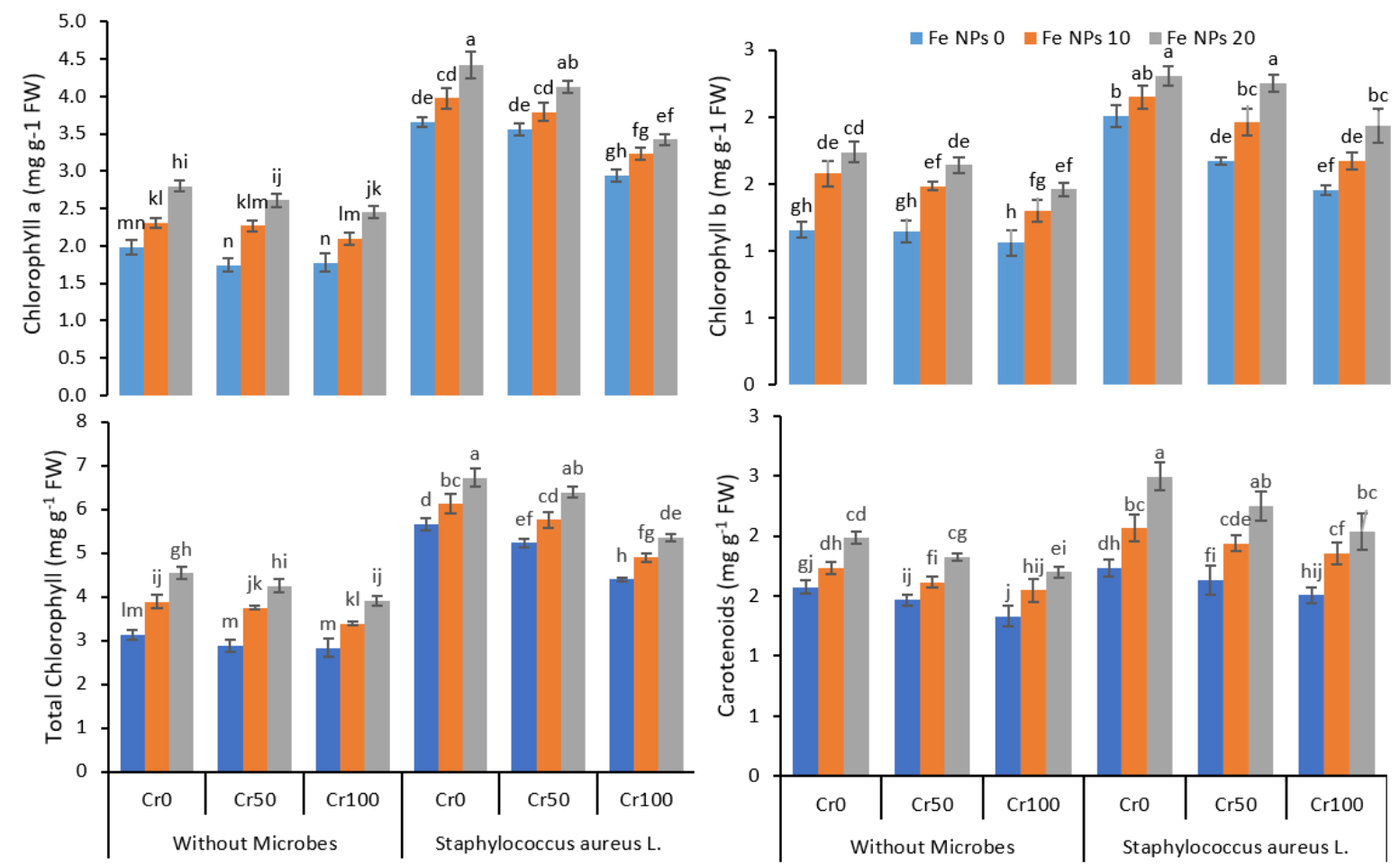

Figure 2. Combined effects of Fe nanoparticles (NPs) $\left(0,10\right.$, and $\left.20 \mathrm{mg} \mathrm{L}^{-1}\right)$ and S. aureus L. on chlorophyll and carotenoids of rice grown under Cr stress $\left(0,50\right.$, and $\left.100 \mathrm{mg} \mathrm{kg}^{-1}\right)$. The mean values of three replicates together with their standard deviation are shown in the figure. Various small letters denote significant differences between different treatments at $p \leq 0.05$.

\subsection{IRGA Parameters}

The increased $\mathrm{Cr}$ concentration steadily decreased the transpiration rate, photosynthetic rate, stomatal conductance, and water use efficiency (Figure 3). The application of Fe NPs significantly improved the transpiration rate, photosynthetic rate, stomatal conductance, and water use efficiency, further boosted by bacterial inoculation in $\mathrm{Cr}$ stressed plants. In plants under $100 \mathrm{mg} \mathrm{kg}^{-1} \mathrm{Cr}$ stress, treated with $20 \mathrm{mg} \mathrm{kg}^{-1} \mathrm{Fe}$ NPs with no bacterial inoculation, the transpiration rate increased from 3.2 to 5 after bacterial inoculation. At $\mathrm{Cr}$ $100 \mathrm{mg} \mathrm{kg}^{-1}$ and Fe NP $20 \mathrm{mg} \mathrm{kg}^{-1}$, a similar increase was observed in photosynthetic rate from 6.5 to $8.7\left(\mu \mathrm{mol} \mathrm{H} \mathrm{H}_{2} \mathrm{O} \mathrm{m}^{-2} \mathrm{~s}^{-1}\right)$, stomatal conductance from 1.4 to $2.7\left(\mathrm{~mol} \mathrm{~m}^{-2} \mathrm{~s}^{-1}\right)$, and water use efficiency from $9.5 \%$ to $11.5 \%$ after bacterial inoculation.

\subsection{Estimation of EL, $M D A$, and $\mathrm{H}_{2} \mathrm{O}_{2}$}

Chromium stress resulted in a substantial increase in electrolyte leakage in rice plants (Figure 4). Under all chromium levels (0, 25, 50, and $\left.100 \mathrm{mg} \mathrm{kg}^{-1}\right)$, plants without Fe NPs treatment showed more EL than plants provided with Fe NPs. Similarly, non-inoculated plants showed more EL as compared to inoculated plants. The combined application of Fe NPs and S. aureus L. significantly reduced the EL in rice plants at all chromium levels. As evident in Figure 5, Fe NPs ( 0 to $20 \mathrm{mg} \mathrm{kg}^{-1}$ ) and S. aureus L. reduced the EL from $58.4 \%$ to $45.1 \%$ at chromium level at $100 \mathrm{mg} \mathrm{kg}^{-1}$. 


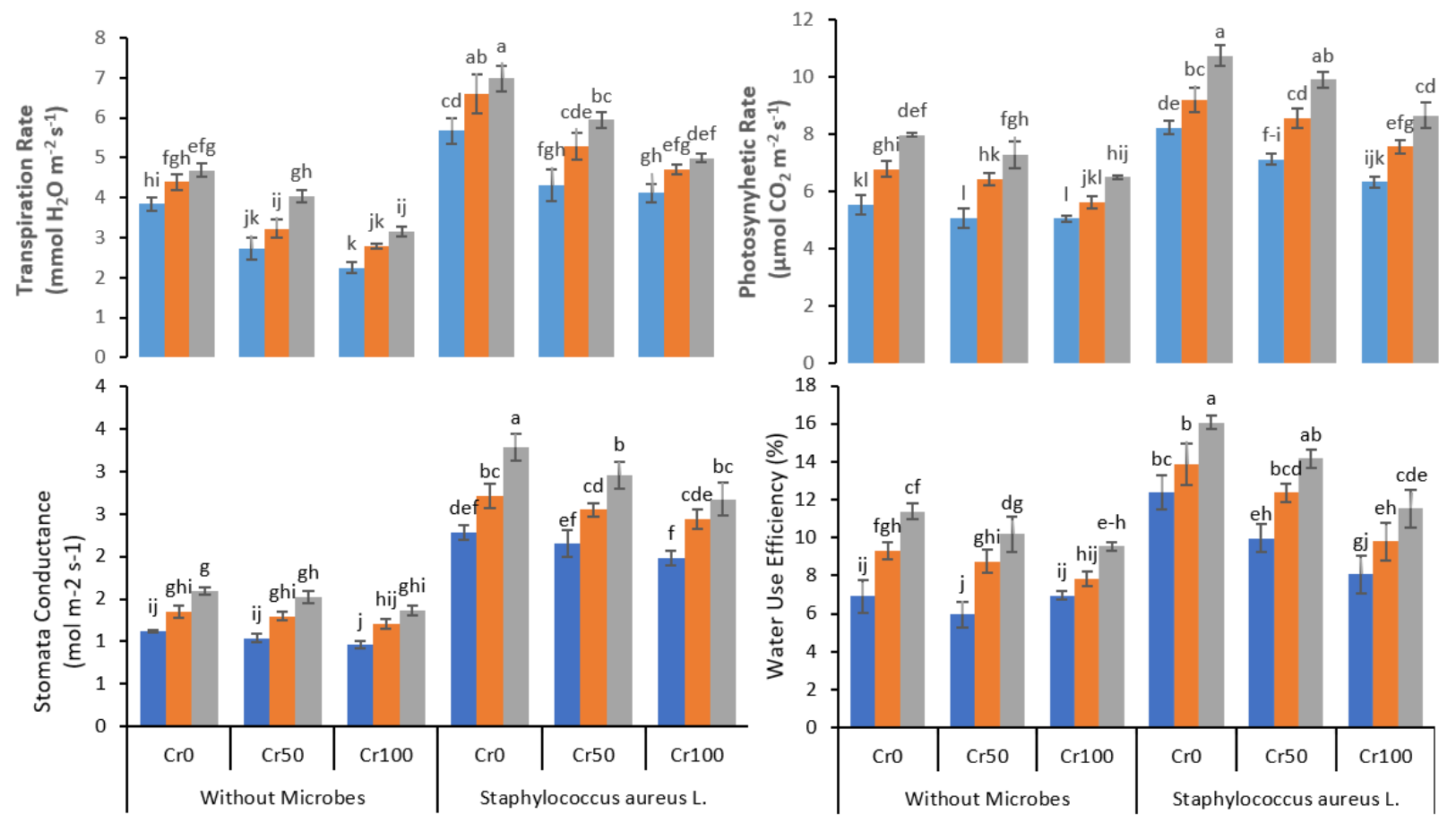

Figure 3. Combined effects of Fe NPs $\left(0,10\right.$, and $\left.20 \mathrm{mg} \mathrm{L}^{-1}\right)$ and $S$. aureus on gas exchange attributes of rice grown under $\mathrm{Cr}$ stress $\left(0,50\right.$, and $\left.100 \mathrm{mg} \mathrm{kg}^{-1}\right)$. The mean values of three replicates together with their standard deviation are shown in figure. Various small letters denote significant differences between different treatments at $p \leq 0.05$.
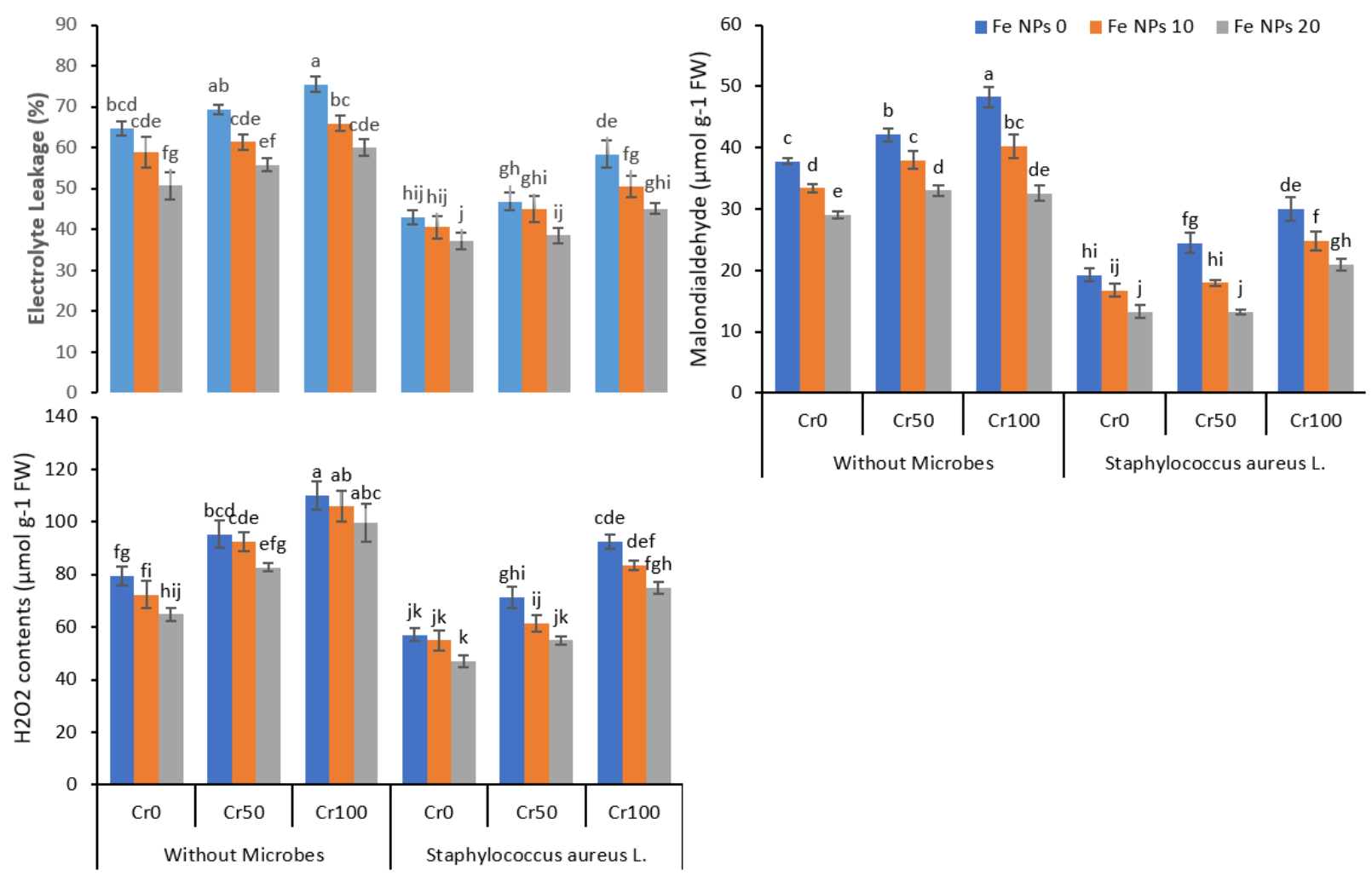

Figure 4. Combined effects of Fe NPs $\left(0,10\right.$, and $\left.20 \mathrm{mg} \mathrm{L}^{-1}\right)$ and S. aureus on oxidative stress indicating parameters of rice grown under $\mathrm{Cr}$ stress $\left(0,50\right.$, and $\left.100 \mathrm{mg} \mathrm{kg}^{-1}\right)$. Mean values of three replicates together with its standard deviation are shown in the figure. Various small letters denote significant differences between different treatments at $p \leq 0.05$. 


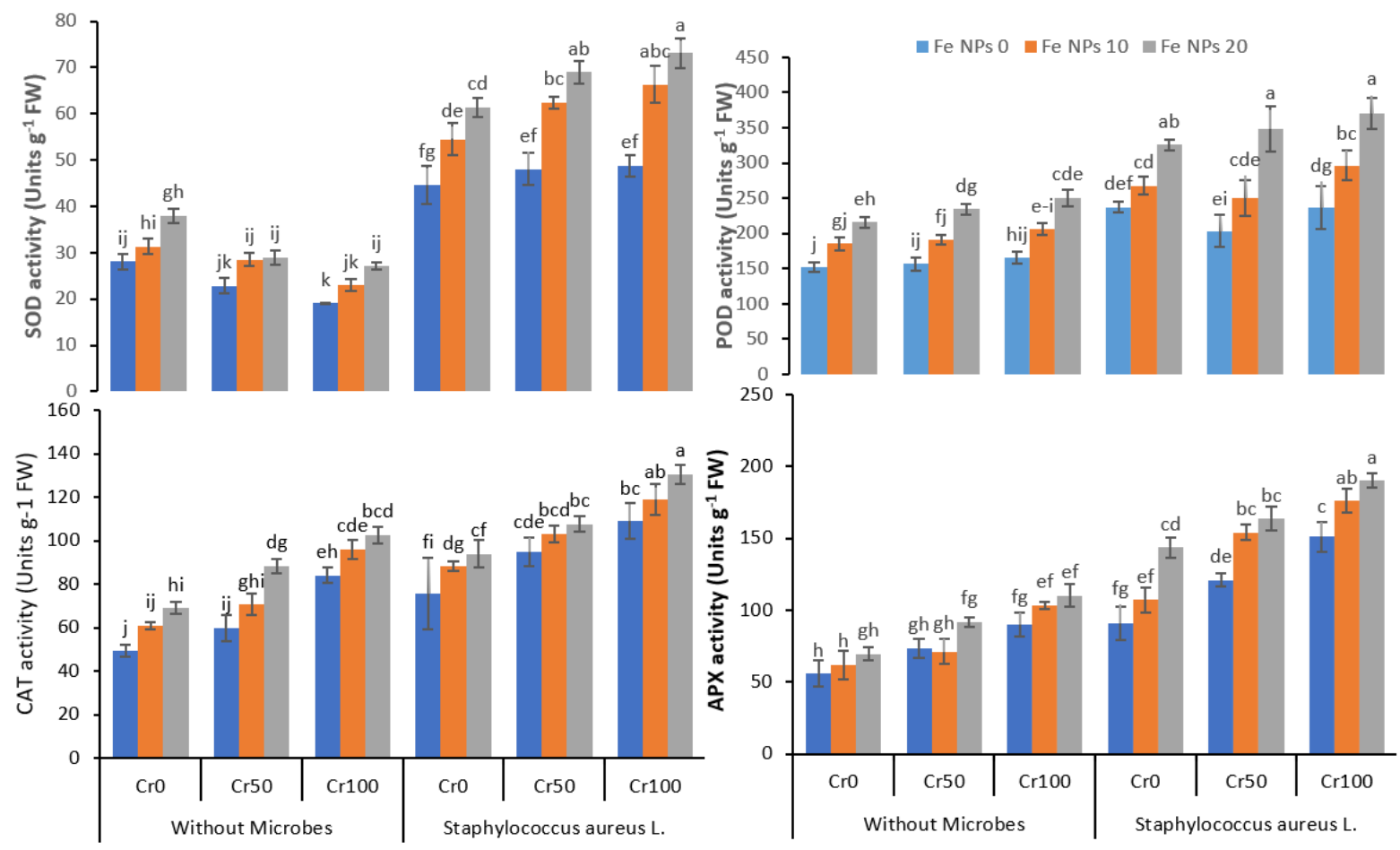

Figure 5. Combined effects of Fe NPs $\left(0,10\right.$, and $\left.20 \mathrm{mg} \mathrm{L}^{-1}\right)$ and S. aureus L. on antioxidants enzymatic activities of rice grown under $\mathrm{Cr}$ stress $\left(0,50\right.$, and $\left.100 \mathrm{mg} \mathrm{kg}^{-1}\right)$. The mean values of three replicates together with their standard deviation are shown in the figure. Various small letters denote significant differences between different treatments at $p \leq 0.05$.

Similarly, Cr toxicity also increased the lipid peroxidation, and a noticeable increase was observed in MDA contents in leaves of rice plants. Maximum MDA contents were observed in plants without Fe NPs and bacterial inoculation under chromium stress at 50 and $100 \mathrm{mg} \mathrm{kg}^{-1}$. Fe NPs reduced the MDA contents in plants under different levels of chromium stress, further decreasing by combining Fe NPs and S. aureus. Likewise, a gradual rise in $\mathrm{H}_{2} \mathrm{O}_{2}$ was observed in plants under different concentrations of chromium. After the Fe NPs and S. aureus L. application individually and combined, a noteworthy decrease was observed in $\mathrm{H}_{2} \mathrm{O}_{2}$ content in plants under $\mathrm{Cr}$ stress.

\subsection{Anti-Oxidant Enzymes Activities}

The findings revealed that SOD activity was significantly increased with the increasing concentration of chromium. The application of Fe NPs enhanced the increase in SOD activity, further boosted by the combined application of Fe NPs and bacterial inoculation. In the plants under chromium stress $\left(100 \mathrm{mg} \mathrm{kg}^{-1}\right)$, the SOD activity increased from $48.7 \mathrm{~g} \mathrm{~g}^{-1} \mathrm{FW}$ (Fe NPs 0) to 73.1 (Fe NPs $20 \mathrm{mg} \mathrm{kg}^{-1}$ ) coupled with bacterial inoculation. Similarly, POD activity also improved from 236.1 to $370.8 \mathrm{~g}^{-1}$ FW by combining Fe NPs and S. aureus L. in plants treated with $100 \mathrm{mg} \mathrm{kg}^{-1}$ of chromium. Likewise, an increase was observed for CAT and APX activity after combining Fe NPs and S. aureus L. The CAT and APX activities increased from 109.1 to $130.5 \mathrm{~g}^{-1} \mathrm{FW}$ and 151.3 to $190.2 \mathrm{~g}^{-1} \mathrm{FW}$, respectively, by increasing Fe NPs from 0 to 20 coupled with bacterial inoculation chromium level $100 \mathrm{mg} \mathrm{kg}^{-1}$.

\subsection{Chromium Uptake by Plants}

The data regarding chromium accumulation in the root, shoot, and grains and Fe accumulation in grains are shown in Figure 6. The increasing chromium concentration from 0 to $100 \mathrm{mg} \mathrm{kg}^{-1}$ also increased the chromium accumulation in the root, shoot, and grains in treatments without Fe NPs and bacterial inoculation. The combined application of 
Fe NPs and S. aureus L. significantly reduced the $\mathrm{Cr}$ uptake and accumulation in the plants. On the other hand, the increasing concentration of $\mathrm{Cr}$ from 0 to $100 \mathrm{mg} \mathrm{kg}^{-1}$ reduced the iron accumulation despite increasing Fe NPs concentration from 0 to $20 \mathrm{mg} \mathrm{kg}^{-1} \mathrm{both}_{\text {in }}$ non-inoculated and inoculated rice plants.
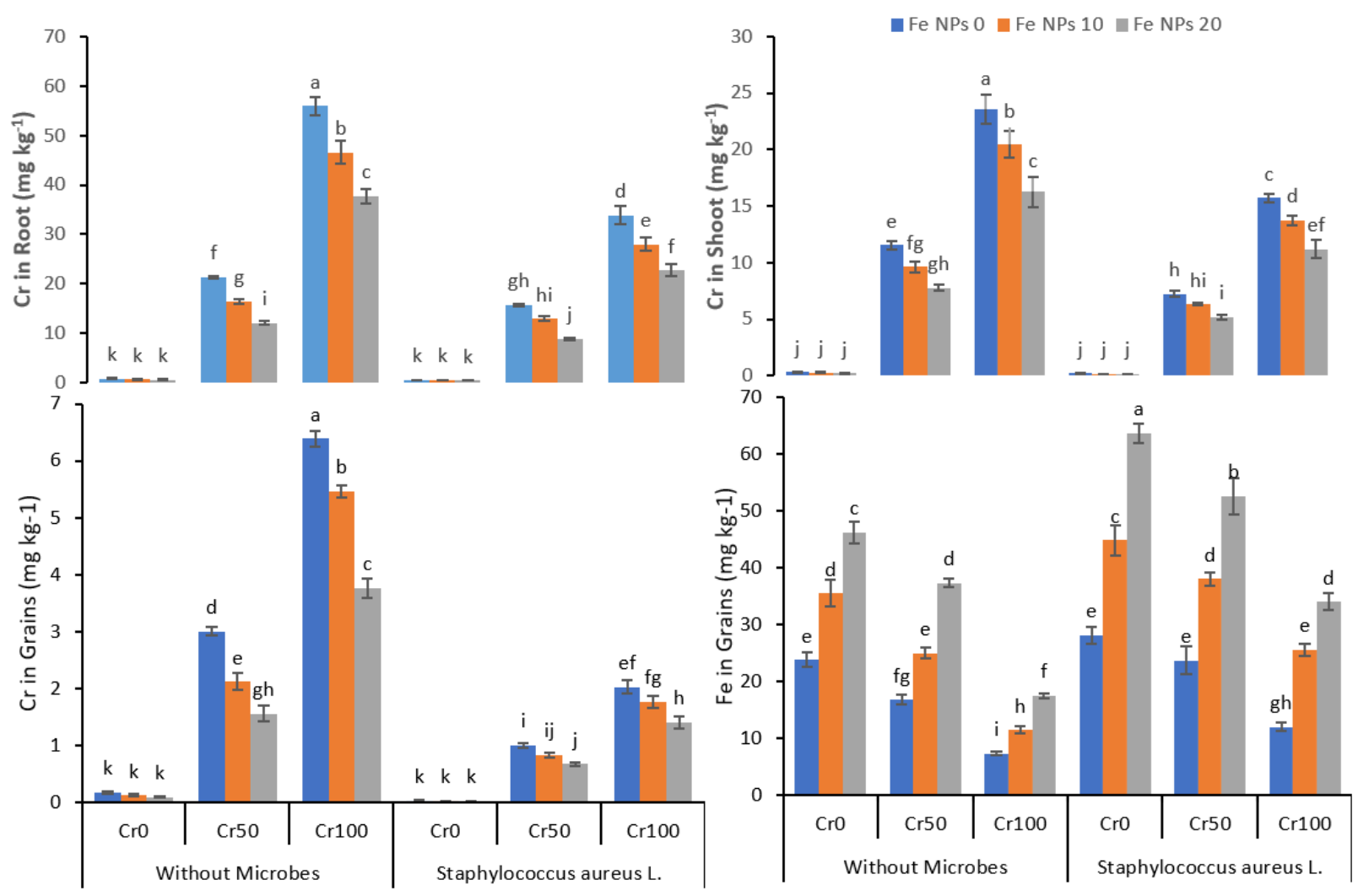

Figure 6. Combined effects of Fe NPs $\left(0,10\right.$, and $\left.20 \mathrm{mg} \mathrm{L}^{-1}\right)$ and S. aureus L. on Cr concentrations in roots, shoot, grains, and Fe concentration in grains of rice grown under $\mathrm{Cr}$ stress $(0,50$, and $100 \mathrm{mg} \mathrm{kg}^{-1}$ ). Mean values of three replicate together with its standard deviation are shown in figure. Various small letters denote significant differences between different treatments at $p \leq 0.05$.

\section{Discussion}

In this study, rice plants were cultivated in Cr-contaminated soil treated with foliar application of Fe NP coupled with microbes to determine the role of Fe NPs and S. aureus $\mathrm{L}$. in alleviating the $\mathrm{Cr}$ induced toxicity in rice plants. According to the findings, the plant growth was significantly reduced under $\mathrm{Cr}$ stress without foliar application of $\mathrm{Fe}$ NPs and/or S. aureus L. These findings are consistent with previous research that has found $\mathrm{Cr}$ to be toxic to various plant species [3,5,46,47]. This disruption in rice growth could be attributed to Cr's adverse effects on plant morphology, physiology, and mineral accumulation [47]. The hexavalent chromium $\left(\mathrm{Cr}^{6+}\right)$ high concentration in plants may restrict the cell division, thus limiting the plant growth, especially roots. It was evident from the results that foliar application of Fe NPs caused a significant positive impact on plants growth. The Fe NPs increased the root and shoot length, root and shoot dry weight, the number of tillers per plant, and leaf area of the rice plants under Cr stress. It has previously been well-demonstrated that nanoparticles have great potential for supplying nutrients to the plants $[48,49]$.

Furthermore, the nanoparticles can activate the metabolic system of the plants, which is beneficial for plant growth and development [49]. Additionally, the role of Fe NPs on plant growth might be attributed to the ability of Fe to stimulate the biosynthesis of chlorophyll and redox process in the plant, which may boost the plant growth [37]. The inoculation of plants with $S$. aureus L. significantly improved all growth parameters in plants under $\mathrm{Cr}$ 
stress. The chromium-resistant bacteria S. aureus L. can reduce the $\mathrm{Cr}^{6+}$, a highly toxic form of chromium, to $\mathrm{Cr}^{3+}$, a less toxic form for plants. The improvement in the plants' growth parameters after inoculation may be linked to the ability of bacteria to detoxify the $\mathrm{Cr}^{6+}$ by their intracellular, enzymatic, and metabolic process [50]. The production of waste such as $\mathrm{H}_{2} \mathrm{~S}$ by bacteria also contributes to detoxifying the $\mathrm{Cr}$ hexavalent form of chromium to the trivalent form of chromium [51].

Chlorophyll is a significant component of chloroplasts and is related to plant photosynthetic rate. Any changes in chlorophyll contents can indicate plant health and plant response to environmental stress [4,52]. Different environmental stress can decrease the chlorophyll contents in the leaves of the plants [52]. The Cr-stress drastically reduced the chlorophyll a, chlorophyll b, total chlorophyll, and carotenoids contents in rice plants (Figure 2). Similarly, the only treatment of plants with $\mathrm{Cr}$ reduced the plant transpiration rate, photosynthetic rate, stomatal conductance, and water use efficiency (Figure 3). The application of Fe NPs reversed the decrease in the chlorophyll and carotenoids contents induced by $\mathrm{Cr}$ toxicity. The Fe NPs have been reported to increase the availability of water and nutrients to the stressed plants, thus improving the plants' physiological performance. Nanoparticles such as iron oxide nanoparticles have been reported to increase the chlorophyll contents in rice plants under Cd stress [48,53]. S. aureus L. further improved the chlorophyll contents in the plants under Cr-stressed by their ability to detoxify the hexavalent chromium into trivalent from their metabolic process. The findings suggest that inoculated bacteria may enhance the plant's ability to withstand the stress of the metal reported earlier by many researchers $[54,55]$. Other researchers reported similar findings where inoculation of plants with metal-resistant bacteria improved the leaf chlorophyll contents by limiting the metals' availability to plants and detoxifying the metals [4].

Fe NPs and bacterial inoculation application also significantly improved the transpiration rate, photosynthetic activity, stomatal conductance, and water use efficiency. The high chlorophyll content from Fe NPs and bacterial inoculation improved the overall photosynthetic process and water use efficiency in rice plants [18].

The exposure of the plants to metal stress may disturb the antioxidant enzymes activities, and it may enhance the oxidative stress in the plants [56]. In this study, the $\mathrm{Cr}$ stress enhanced the EL, MDA, and $\mathrm{H}_{2} \mathrm{O}_{2}$ concentration, and it enhanced the antioxidant enzymes activities in the rice plants (Figures 4 and 5). The $\mathrm{Cr}$ stress may trigger oxidative stress in plants and initiate ROS overproduction in plants [57]. This oxidative stress and overproduction of ROS might disturb the physiological process in plants and ultimately decrease plant growth. The exogenous application of Fe NPs significantly ameliorated the $\mathrm{Cr}$-induced oxidative stress in the rice plants, which was evident by the reduced level of EL, MDA, and $\mathrm{H}_{2} \mathrm{O}_{2}$ and increased antioxidant enzymes activities in plants under $\mathrm{Cr}$ stress (Figures 4 and 5). The Fe NPs can decrease ROS production and improve the activities of the enzyme in the rice plants under Cr stress by improving the chlorophyll contents and better transpiration [58]. The inoculation of rice plants with bacteria also significantly decreased the EL, MDA, and $\mathrm{H}_{2} \mathrm{O}_{2}$ contents and increased antioxidants enzymes activities by detoxifying the chromium. The plants treated with Ag-nano-particle modulated ABA, IAA, and GA production and increased the proline production. Additionally, it also reduced the oxidative stress, and augmented bacteria detoxified the toxic effect of $\mathrm{Pb}, \mathrm{Cd}$, and $\mathrm{Ni}$ on maize plants [59]. Our findings suggest that foliar application of Fe NPs combined with bacterial inoculation can help rice plants cope with $\mathrm{Cr}$ stress by regulating the plant's defense system.

The build-up of toxic metals in the plant root and shoots has a deleterious effect on plant growth. The incorporation of these plants into the food chain may harm human health. The finding of our study suggested that the accumulation of $\mathrm{Cr}$ in the rice plant was dose-dependent in the absence of Fe NPs and bacterial inoculation (Figure 6). These findings were comparable to previous studies indicating the increased build-up of metals in the plants with increasing doses of heavy metals [48,60]. The foliar application of Fe NPs resulted in decreased accumulation of $\mathrm{Cr}$ in the root, shoot, and grains despite the 
increased dose of chromium. Iron is an essential nutrient required for the healthy growth, development, and production of the plant. The foliar application of Fe at the nanoscale increased the bioavailability compared to the bulk supply of micronutrients [61]. Thus, the application of Fe NPs might enhance the mineral contents in the plants as compared to the control and reduced the Cr uptake by the plants. Fe NPs as iron oxides have been reported to increase the yield parameters of different crops such as soybean and white and green beans by increasing the nutrients contents in the plants $[62,63]$.

Similarly, the carbon nanoparticles combined with nitrogenous fertilizers improved the yield of the rice crops grown on saline-alkali soil by strengthening the plants to tolerate environmental stress [64]. The inoculation of $\mathrm{Cr}$ resistant bacteria and Fe NPs further reduced the $\mathrm{Cr}$ accumulation in roots, shoots, and grains. It might be attributed to the ability of bacteria to transform the hexavalent chromium into a less toxic trivalent form. Bacteria also can eliminate the toxic metals through their metabolic process and reduce the bioavailability of toxic metal to plants by adsorption to metals ions [59]. Many researchers reported similar findings where inoculation of plants improved the plants' growth and reduced the bioavailability of heavy metals and accumulation in the plants [65-67]. The increasing dose of Fe NPs increased the accumulation of Fe NPs in the rice grains in the absence of chromium. However, the increasing dose of $\mathrm{Cr}$ reduces the Fe NPs accumulation in the rice grains. The nanoparticles can sorb the heavy metals and alleviate the toxicity of the metal as sulfidized nano zero valent iron nZVI (FeSSi) sorb cadmium (Cd) from an aqueous medium and alleviated the Cd toxicity by removing $80 \%$ of the cadmium in the first hour [68].

\section{Conclusions}

Chromium stress drastically reduced rice plant growth and photosynthesis and increased plants' EL, MDA, and $\mathrm{H}_{2} \mathrm{O}_{2}$. Fe NPs improved photosynthesis and carotenoid contents, reduced oxidative stress, and thus improved the plants' growth and yield by reducing the chromium toxicity in the plants under stress. In addition, the inoculation of plants with $S$. aureus $\mathrm{L}$. further enhanced plant growth by decreasing the $\mathrm{Cr}$ toxicity by transforming $\mathrm{Cr}^{6+}$ to $\mathrm{Cr}^{3+}$ and reducing the bioavailability of $\mathrm{Cr}$ to rice plants. Finally, the integrated application of Fe NPs and S. aureus L. has proven a promising approach for alleviating $\mathrm{Cr}$ toxicity from contaminated soil and enhancing the plants' ability to endure metals-induced toxicity. Further work should focus on the standardization of the application of NPs in the crops to eliminate the contamination effect of nanoparticles. There is a need to identify and isolate the metal-resistant bacteria with unique abilities to perform efficiently with metal NPs to alleviate the metals induced toxicity in plants.

Author Contributions: H.F.A.: conceptualization, investigation, methodology, formal analysis, and writing-review and editing. S.A.: conceptualization, supervision, project administration, formal analysis, validation, investigation, methodology, and writing — original draft. All authors have read and agreed to the published version of the manuscript.

Funding: This project was funded by the Deanship of Scientific Research (DSR) at King Abdulaziz University, Jeddah, under grant no. (G: 269-130-1442).

Institutional Review Board Statement: This research did not need any institutional review board statement because it does not include any animal model.

Informed Consent Statement: Not applicable.

Data Availability Statement: The data presented in the manuscript is the sole data and no other data is linked with this data.

Acknowledgments: This project was funded by the Deanship of Scientific Research (DSR) at King Abdulaziz University, Jeddah, under grant no. (G: 269-130-1442). The authors, therefore, acknowledge with thanks DSR for technical and financial support.

Conflicts of Interest: We confirm that all authors of the manuscript have no conflict of interest to declare. 


\section{References}

1. DesMarias, T.L.; Costa, M. Mechanisms of chromium-induced toxicity. Curr. Opin. Toxicol. 2019, 14, 1-7. [CrossRef] [PubMed]

2. Pavesi, T.; Moreira, J.C. Mechanisms and individuality in chromium toxicity in humans. J. Appl. Toxicol. 2020, 40, 1183-1197. [CrossRef] [PubMed]

3. Ahmad, R.; Ali, S.; Abid, M.; Rizwan, M.; Ali, B.; Tanveer, A.; Ahmad, I.; Azam, M.; Ghani, M.A. Glycinebetaine alleviates the chromium toxicity in Brassica oleracea L. by suppressing oxidative stress and modulating the plant morphology and photosynthetic attributes. Environ. Sci. Pollut. Res. 2020, 27, 1101-1111. [CrossRef] [PubMed]

4. Zeng, F.; Zahoor, M.; Waseem, M.; Anayat, A.; Rizwan, M.; Ahmad, A.; Yasmeen, T.; Ali, S.; El-Sheikh, M.A.; Alyemeni, M.N. Influence of metal-resistant staphylococcus aureus strain $\mathrm{K} 1$ on the alleviation of chromium stress in wheat. Agronomy 2020, 10, 1354. [CrossRef]

5. Sharma, A.; Kapoor, D.; Wang, J.; Shahzad, B.; Kumar, V.; Bali, A.S.; Jasrotia, S.; Zheng, B.; Yuan, H.; Yan, D. Chromium bioaccumulation and its impacts on plants: An overview. Plants 2020, 9, 100. [CrossRef] [PubMed]

6. Zaheer, I.E.; Ali, S.; Saleem, M.H.; Imran, M.; Alnusairi, G.S.H.; Alharbi, B.M.; Riaz, M.; Abbas, Z.; Rizwan, M.; Soliman, M.H. Role of iron-lysine on morpho-physiological traits and combating chromium toxicity in rapeseed (Brassica napus L.) plants irrigated with different levels of tannery wastewater. Plant Physiol. Biochem. 2020, 155, 70-84. [CrossRef]

7. Qian, Q.; Guo, L.; Smith, S.M.; Li, J. Breeding high-yield superior quality hybrid super rice by rational design. Natl. Sci. Rev. 2016, 3, 283-294. [CrossRef]

8. Zarei, I.; Brown, D.G.; Nealon, N.J.; Ryan, E.P. Rice bran metabolome contains amino acids, vitamins \& cofactors, and phytochemicals with medicinal and nutritional properties. Rice 2017, 10, 24.

9. Mao, C.; Song, Y.; Chen, L.; Ji, J.; Li, J.; Yuan, X.; Yang, Z.; Ayoko, G.A.; Frost, R.L.; Theiss, F. Human health risks of heavy metals in paddy rice based on transfer characteristics of heavy metals from soil to rice. Catena 2019, 175, 339-348. [CrossRef]

10. Williams, P.N.; Lei, M.; Sun, G.; Huang, Q.; Lu, Y.; Deacon, C.; Meharg, A.A.; Zhu, Y.-G. Occurrence and partitioning of cadmium, arsenic and lead in mine impacted paddy rice: Hunan, China. Environ. Sci. Technol. 2009, 43, 637-642. [CrossRef]

11. Muthayya, S.; Sugimoto, J.D.; Montgomery, S.; Maberly, G.F. An overview of global rice production, supply, trade, and consumption. Ann. N. Y. Acad. Sci. 2014, 1324, 7-14. [CrossRef] [PubMed]

12. Ochoa, M.; Tierra, W.; Tupuna-Yerovi, D.S.; Guanoluisa, D.; Otero, X.L.; Ruales, J. Assessment of cadmium and lead contamination in rice farming soils and rice (Oryza sativa L.) from Guayas province in Ecuador. Environ. Pollut. 2020, 260, 114050. [CrossRef] [PubMed]

13. Xie, L.; Hao, P.; Cheng, Y.; Ahmed, I.M.; Cao, F. Effect of combined application of lead, cadmium, chromium and copper on grain, leaf and stem heavy metal contents at different growth stages in rice. Ecotoxicol. Environ. Saf. 2018, 162, 71-76. [CrossRef] [PubMed]

14. Liu, W.-X.; Shen, L.-F.; Liu, J.-W.; Wang, Y.-W.; Li, S.-R. Uptake of toxic heavy metals by rice (Oryza sativa L.) cultivated in the agricultural soil near Zhengzhou City, People's Republic of China. Bull. Environ. Contam. Toxicol. 2007, 79, 209-213. [CrossRef]

15. Sallah-Ud-Din, R.; Farid, M.; Saeed, R.; Ali, S.; Rizwan, M.; Tauqeer, H.M.; Bukhari, S.A.H. Citric acid enhanced the antioxidant defense system and chromium uptake by Lemna minor L. grown in hydroponics under Cr stress. Environ. Sci. Pollut. Res. 2017, 24, 17669-17678. [CrossRef]

16. Zaheer, I.E.; Ali, S.; Rizwan, M.; Farid, M.; Shakoor, M.B.; Gill, R.A.; Najeeb, U.; Iqbal, N.; Ahmad, R. Citric acid assisted phytoremediation of copper by Brassica napus L. Ecotoxicol. Environ. Saf. 2015, 120, 310-317. [CrossRef] [PubMed]

17. Zeng, F.; Qiu, B.; Wu, X.; Niu, S.; Wu, F.; Zhang, G. Glutathione-mediated alleviation of chromium toxicity in rice plants. Biol. Trace Elem. Res. 2012, 148, 255-263. [CrossRef]

18. Tiwari, S.; Lata, C. Heavy metal stress, signaling, and tolerance due to plant-associated microbes: An overview. Front. Plant Sci. 2018, 9, 452. [CrossRef]

19. Kumar, A.; Gupta, K.; Dixit, S.; Mishra, K.; Srivastava, S. A review on positive and negative impacts of nanotechnology in agriculture. Int. J. Environ. Sci. Technol. 2019, 16, 2175-2184. [CrossRef]

20. Mitter, N.; Hussey, K. Moving policy and regulation forward for nanotechnology applications in agriculture. Nat. Nanotechnol. 2019, 14, 508-510. [CrossRef]

21. Kumar, S.; Palve, A.; Joshi, C.; Srivastava, R.K. Crop biofortification for iron (Fe), zinc (Zn) and vitamin A with transgenic approaches. Heliyon 2019, 5, e01914. [CrossRef] [PubMed]

22. Salatin, S.; Maleki Dizaj, S.; Yari Khosroushahi, A. Effect of the surface modification, size, and shape on cellular uptake of nanoparticles. Cell Biol. Int. 2015, 39, 881-890. [CrossRef] [PubMed]

23. Das, M.; Saxena, N.; Dwivedi, P.D. Emerging trends of nano-particles application in food technology: Safety paradigms. Nanotoxicology 2009, 3, 10-18. [CrossRef]

24. Husen, A.; Siddiqi, K.S. Phytosynthesis of nano-particles: Concept, controversy and application. Nanoscale Res. Lett. 2014, 9, 229. [CrossRef] [PubMed]

25. Rout, G.R.; Sahoo, S. Role of iron in plant growth and metabolism. Rev. Agric. Sci. 2015, 3, 1-24. [CrossRef]

26. Rajput, V.D.; Minkina, T.; Sushkova, S.; Tsitsuashvili, V.; Mandzhieva, S.; Gorovtsov, A.; Nevidomskyaya, D.; Gromakova, N. Effect of nanoparticles on crops and soil microbial communities. J. Soils Sediments 2018, 18, 2179-2187. [CrossRef]

27. Du, W.; Sun, Y.; Ji, R.; Zhu, J.; Wu, J.; Guo, $\mathrm{H}$. $\mathrm{TiO}_{2}$ and $\mathrm{ZnO}$ nano-particles negatively affect wheat growth and soil enzyme activities in agricultural soil. J. Environ. Monit. 2011, 13, 822-828. [CrossRef] 
28. Raja, K.; Sowmya, R.; Sudhagar, R.; Moorthy, P.S.; Govindaraju, K.; Subramanian, K.S. Biogenic ZnO and Cu nanoparticles to improve seed germination quality in blackgram (Vigna mungo). Mater. Lett. 2019, 235, 164-167. [CrossRef]

29. Subbaiah, L.V.; Prasad, T.N.V.K.V.; Krishna, T.G.; Sudhakar, P.; Reddy, B.R.; Pradeep, T. Novel effects of nanoparticulate delivery of zinc on growth, productivity, and zinc biofortification in maize (Zea mays L.). J. Agric. Food Chem. 2016, 64, 3778-3788. [CrossRef]

30. Venkatachalam, P.; Priyanka, N.; Manikandan, K.; Ganeshbabu, I.; Indiraarulselvi, P.; Geetha, N.; Muralikrishna, K.; Bhattacharya, R.C.; Tiwari, M.; Sharma, N. Enhanced plant growth promoting role of phycomolecules coated zinc oxide nanoparticles with P supplementation in cotton (Gossypium hirsutum L.). Plant Physiol. Biochem. 2017, 110, 118-127. [CrossRef]

31. Akram, R.; Turan, V.; Hammad, H.M.; Ahmad, S.; Hussain, S.; Hasnain, A.; Maqbool, M.M.; Rehmani, M.I.A.; Rasool, A.; Masood, N. Fate of Organic and Inorganic Pollutants in Paddy Soils. In Environmental Pollution of Paddy Soils; Springer: Cham, Switzerland, 2018; pp. 197-214.

32. Ahmed, A. How chromium-resistant bacteria can improve corn growth in chromium-contaminated growing medium. Pol. J. Environ. Stud. 2016, 25, 2357-2365.

33. Bouyoucos, G.J. Hydrometer method improved for making particle size analyses of soils. Agron. J. 1962, 54, 464-465. [CrossRef]

34. Soltanpour, P.N. Use of ammonium bicarbonate DTPA soil test to evaluate elemental availability and toxicity. Commun. Soil Sci. Plant Anal. 1985, 16, 323-338. [CrossRef]

35. Amacher, M.C. Nickel, Cadmium, and Lead. In Methods of Soil Analysis; Sparks, D.L., Ed.; Part 3; Chemical Methods; Soil Science Society of America: Madison, WI, USA, 1996.

36. Rizwan, M.; Ali, S.; Ali, B.; Adrees, M.; Arshad, M.; Hussain, A.; ur Rehman, M.Z.; Waris, A.A. Zinc and iron oxide nanoparticles improved the plant growth and reduced the oxidative stress and cadmium concentration in wheat. Chemosphere 2019, 214, 269-277. [CrossRef] [PubMed]

37. Zulaika, E.; Sembiring, L. Indigenous mercury resistant bacterial isolates belong to the genus Bacillus from Kalimas Surabaya as a potential mercury bioreducer. J. Appl. Environ. Biol. Sci. 2014, 4, 72-76.

38. Litchtenthaler, H.K. Chlorophylls and carotenoids: Pigments of photosynthetic biomembranes. In Methods in Enzymology; Academic Press: Orlando, FL, USA, 1987; Volume 148, pp. 350-381.

39. Zhang, J.; Kirkham, M.B. Drought-stress-induced changes in activities of superoxide dismutase, catalase, and peroxidase in wheat species. Plant Cell Physiol. 1994, 35, 785-791. [CrossRef]

40. Dionisio-Sese, M.L.; Tobita, S. Antioxidant responses of rice seedlings to salinity stress. Plant Sci. 1998, 135, 1-9. [CrossRef]

41. Jana, S.; Choudhuri, M.A. Senescence in submerged aquatic angiosperms: Effects of heavy metals. N. Phytol. 1982, 90, 477-484. [CrossRef]

42. Zhang, X.Z. The measurement and mechanism of lipid peroxidation and SOD, POD and CAT activities in biological system. In Research Methodology of Crop Physiology; Agriculture Press: Beijing, China, 1992; pp. 208-211.

43. Nakano, Y.; Asada, K. Hydrogen peroxide is scavenged by ascorbate-specific peroxidase in spinach chloroplasts. Plant Cell Physiol. 1981, 22, 867-880.

44. Aebi, H. Catalase in vitro. Methods Enzymol. 1984, 105, 121-126.

45. Rehman, M.Z.; Rizwan, M.; Ghafoor, A.; Naeem, A.; Ali, S.; Sabir, M.; Qayyum, M.F. Effect of inorganic amendments for in situ stabilization of cadmium in contaminated soils and its phyto-availability to wheat and rice under rotation. Environ. Sci. Pollut. Res. 2015, 22, 16897-16906. [CrossRef] [PubMed]

46. Alprol, A.E.; Heneash, A.M.M.; Soliman, A.M.; Ashour, M.; Alsanie, W.F.; Gaber, A.; Mansour, A.T. Assessment of Water Quality, Eutrophication, and Zooplankton Community in Lake Burullus, Egypt. Diversity 2021, 13, 268. [CrossRef]

47. Mukta, R.H.; Khatun, M.R.; Nazmul Huda, A.K.M. Calcium induces phytochelatin accumulation to cope with chromium toxicity in rice (Oryza sativa L.). J. Plant Interact. 2019, 14, 295-302. [CrossRef]

48. Huda, A.K.M.N.; Hossain, M.; Mukta, R.H.; Khatun, M.R.; Haque, M.A. EDTA-enhanced Cr detoxification and its potential toxicity in rice (Oryza sativa L.). Plant Stress 2021, 2, 100014. [CrossRef]

49. Ali, S.; Rizwan, M.; Noureen, S.; Anwar, S.; Ali, B.; Naveed, M.; Abd_Allah, E.F.; Alqarawi, A.A.; Ahmad, P. Combined use of biochar and zinc oxide nanoparticle foliar spray improved the plant growth and decreased the cadmium accumulation in rice (Oryza sativa L.) plant. Environ. Sci. Pollut. Res. 2019, 26, 11288-11299. [CrossRef]

50. Guo, A.; Hu, Y.; Shi, M.; Wang, H.; Wu, Y.; Wang, Y. Effects of iron deficiency and exogenous sucrose on the intermediates of chlorophyll biosynthesis in Malus halliana. PLoS ONE 2020, 15, e0232694. [CrossRef] [PubMed]

51. Sarkar, A.; Sar, P.; Islam, E. Hexavalent chromium reduction by Microbacterium oleivorans A1: A possible mechanism of chromate-detoxification and-bioremediation. Recent Pat. Biotechnol. 2015, 9, 116-129. [CrossRef]

52. Alprol, A.E.; Ashour, M.; Mansour, A.T.; Alzahrani, O.M.; Mahmoud, S.F.; Gharib, S.M. Assessment of Water Quality and Phytoplankton Structure of Eight Alexandria Beaches, Southeastern Mediterranean Sea, Egypt. Egypt. J. Mar. Sci. Eng. 2021, 9, 1328. [CrossRef]

53. Sahinkaya, E.; Kilic, A.; Altun, M.; Komnitsas, K.; Lens, P.N.L. Hexavalent chromium reduction in a sulfur reducing packed-bed bioreactor. J. Hazard. Mater. 2012, 219, 253-259. [CrossRef]

54. Sebastian, A.; Nangia, A.; Prasad, M.N.V. A green synthetic route to phenolics fabricated magnetite nanoparticles from coconut husk extract: Implications to treat metal contaminated water and heavy metal stress in Oryza sativa L. J. Clean. Prod. 2018, 174, 355-366. [CrossRef] 
55. Shahid, M.J.; AL-surhanee, A.A.; Kouadri, F.; Ali, S.; Nawaz, N.; Afzal, M.; Rizwan, M.; Ali, B.; Soliman, M.H. Role of microorganisms in the remediation of wastewater in floating treatmentwetlands: A review. Sustainability 2020, 12, 5559. [CrossRef]

56. Li, H.Q.; Jiang, X.W. Inoculation with plant growth-promoting bacteria (PGPB) improves salt tolerance of maize seedling. Russ. J. Plant Physiol. 2017, 64, 235-241. [CrossRef]

57. Kouki, R.; Ayachi, R.; Ferreira, R.; Sleimi, N. Behavior of Cucumis sativus L. in presence of aluminum stress: Germination, plant growth, and antioxidant enzymes. Food Sci. Nutr. 2021, 9, 3280-3288. [CrossRef] [PubMed]

58. Shirani Bidabadi, S. The role of Fe-nano particles in scarlet sage responses to heavy metals stress. Int. J. Phytoremediat. 2020, 22, 1259-1268. [CrossRef]

59. Khan, N.; Bano, A. Role of plant growth promoting rhizobacteria and Ag-nano particle in the bioremediation of heavy metals and maize growth under municipal wastewater irrigation. Int. J. Phytoremediat. 2016, 18, 211-221. [CrossRef]

60. Hussain, A.; Ali, S.; Rizwan, M.; ur Rehman, M.Z.; Javed, M.R.; Imran, M.; Chatha, S.A.S.; Nazir, R. Zinc oxide nanoparticles alter the wheat physiological response and reduce the cadmium uptake by plants. Environ. Pollut. 2018, 242, 1518-1526. [CrossRef]

61. Kasivelu, G.; Selvaraj, T.; Malaichamy, K.; Kathickeyan, D.; Shkolnik, D.; Chaturvedi, S. Nano-micronutrients [ $\gamma$-Fe2O3 (iron) and $\mathrm{ZnO}$ (zinc)]: Green preparation, characterization, agro-morphological characteristics and crop productivity studies in two crops (rice and maize). N. J. Chem. 2020, 44, 11373-11383. [CrossRef]

62. Fan, L.; Wang, Y.; Shao, X.; Geng, Y.; Wang, Z.; Ma, Y.; Liu, J. Effects of combined nitrogen fertilizer and nano-carbon application on yield and nitrogen use of rice grown on saline-alkali soil. J. Food, Agric. Environ. 2012, 10, 558-562.

63. Servin, A.; Elmer, W.; Mukherjee, A.; De la Torre-Roche, R.; Hamdi, H.; White, J.C.; Bindraban, P.; Dimkpa, C. A review of the use of engineered nanomaterials to suppress plant disease and enhance crop yield. J. Nanopart. Res. 2015, 17, 92. [CrossRef]

64. Zubair, M.; Shakir, M.; Ali, Q.; Rani, N.; Fatima, N.; Farooq, S.; Shafiq, S.; Kanwal, N.; Ali, F.; Nasir, I.A. Rhizobacteria and phytoremediation of heavy metals. Environ. Technol. Rev. 2016, 5, 112-119. [CrossRef]

65. Afzal, M.; Rehman, K.; Shabir, G.; Tahseen, R.; Ijaz, A.; Hashmat, A.J.; Brix, H. Large-scale remediation of oil-contaminated water using floating treatment wetlands. npj Clean Water 2019, 2, 3. [CrossRef]

66. Shahid, M.J.; Ali, S.; Shabir, G.; Siddique, M.; Rizwan, M.; Seleiman, M.F.; Afzal, M. Comparing the performance of four macrophytes in bacterial assisted floating treatment wetlands for the removal of trace metals $(\mathrm{Fe}, \mathrm{Mn}, \mathrm{Ni}, \mathrm{Pb}$, and $\mathrm{Cr})$ from polluted river water. Chemosphere 2020, 243, 125353. [CrossRef] [PubMed]

67. Nafees, M.; Ali, S.; Naveed, M.; Rizwan, M. Efficiency of biogas slurry and Burkholderia phytofirmans PsJN to improve growth, physiology, and antioxidant activity of Brassica napus L. in chromium-contaminated soil. Environ. Sci. Pollut. Res. 2018, 25, 6387-6397. [CrossRef]

68. Stevenson, L.M.; Adeleye, A.S.; Su, Y.; Zhang, Y.; Keller, A.A.; Nisbet, R.M. Remediation of cadmium toxicity by sulfidized nano-iron: The importance of organic material. ACS Nano 2017, 11, 10558-10567. [CrossRef] [PubMed] 